DOI: https://doi.org/10.32839/2304-5809/2021-4-92-32

УДК 7.091.4

Овчінніков А.В.

Львівський національний університет імені Івана Франка

\title{
МИСТЕЦЬКИЙ ФЕСТИВАЛЬ ЯК ІНСТРУМЕНТ РОЗВИТКУ ТАНЦЮВАЛЬНОЇ СПІЛЬНОТИ: ПРОБЛЕМНІ ПИТАННЯ
}

\begin{abstract}
Анотація. У статті розглянуто та проаналізовано загальні тенденції організації та проведення фестивалів танщю в Україні в період з набуття Незалежності у 1991 році до сьогодення. Автор дослідив наукові статті та звіти українських та іноземних дослідників щодо культурної та мистецької складової мистецьких хореографічних фестивалів, аспектів їх організації та проведення. Автором з'ясовано та окреслено причини підвищення інтересу до занять танцем та хореографіею серед різних вікових категорій населення України протягом двох останніх десятирічь. Танець $є$ частиною традиційною культури в Україні і через це кількість танцювальних шкіл, кафедр хореографії та танцювальних гуртків постійно зростае. Нові телевізійні шоу, що мають у своїй складовій хореографічні виступи та змагання привертають увагу і викликають інтерес нової аудиторії. Автором доведено, що низька якість рівня фестивалів танцю та їх оріентація лише на отримання прибутку е одніею з причин стагнації розвитку незалежних професійних танцювальних компаній. Запропоновано критерії для аналізу хореографічних фестивалів за якими їх можна умовно розділити на «професійні» та «аматорські». В процесі дослідження приділено увагу наявності експертної ради або журі, освітньої та нетворкінгової складової, технічному забезпеченню та спроможності виконати технічний райдер учасників. На прикладі найбільших українських фестивалів розглянуто глядацькі аудиторії фестивалів а також наявність та ефективність комунікаційних стратегіїй, що впливають на відвідуваність. Автором проаналізовано причини загального зниження виконавського та хореографічного рівня учасників більшості регіональних фестивалів. Зазначено, що відсутність експертних рад та фахового професійного журі, що здійснюе відбір учасників сприятиме зниженню цього рівня. За наведеними критеріями досліджено спроможність фестивалів формувати професійну спільноту та впливати на її сталість, в тому числі мотивувати учасників фестивалів до творчої діяльності, одержання професійної освіти та професіоналізації. Зроблено висноски щодо перспективи розвитку професійних танцювальних компаній у сучасних умовах. Особливо відзначено роль фестивалю сучасного танцювального театру Zelyonka FEST у сприянні розвитку спільноти.
\end{abstract}

Ключові слова: фестиваль, сучасний танець, сучасна хореографія, танцювальна спільнота, комунікаційна стратегія, спектакль, перформанс, глядацька аудиторія, експертна рада, журі, професійна освіта.

Ovchinnikov Anton

Lviv Ivan Franko National University

\section{ART FESTIVAL AS A TOOL FOR THE DEVELOPMENT OF THE DANCE COMMUNITY: PROBLEM ISSUES}

Summary. The article considers and analyzes the general tendencies of organization and management of dance festivals in Ukraine in the period from gaining Independence in 1991 to the present. The author researched scientific articles and reports of Ukrainian and foreign researchers on the cultural and artistic component of choreographic art festivals, aspects of their organization and management. The author clarifies and outlines the reasons for the increase in interest in dance and choreography among different age groups of the population of Ukraine during the last two decades. Dance is part of the traditional culture in Ukraine and because of this the number of dance schools, choreography departments and dance groups is constantly growing. New TV shows with choreographic performances and competitions attract attention and interest of new audiences. The author proved that the low quality of the level of dance festivals and their focus only on making a profit is one of the reasons for the stagnation of the development of independent professional dance companies. Criteria for the analysis of choreographic festivals according to which they can be divided into «professional» and «amateur» are offered. The study focuses on the presence of an expert council or jury, educational and non-networking component, technical support and the ability to perform the technical rider of the participants. On the example of the largest Ukrainian festivals, the audience of the festivals is considered, as well as the availability and effectiveness of communication strategies that affect attendance. The author analyzes the reasons for the general decline in the performance and choreography of participants in most regional festivals. It is noted that the lack of expert councils and a professional professional jury that selects participants will help reduce this level. According to these criteria, the ability of festivals to form a professional community and influence its sustainability, including motivating festival participants to creative activities, professional education and professionalization. Conclusions are made on the prospects of development of professional dance companies in modern conditions. The role of the Zelyonka FEST contemporary dance theater festival in promoting community development was especially noted.

Keywords: festival, management, organization, contemporary dance, modern choreography, dance community, communication strategy, spectacle, performance, audience, board of experts, jury, professional education.

Постановка проблеми. Останні десять років в Україні спостерігається сплеск інтересу до занять різними формами танцю. В залежності від віку, власних можливостей та інтересів люди обирають танець з різних міркувань та вподобань. Комусь він потрібен як засіб для соціалізації в середині групи, в якості рухової терапії, як спосіб проведення вільного

(C) Овчінніков А.В., 2021 
часу, в інших випадках - як можливість підвищити рухово-редлексійні навантаження задля фрізичного та емоційного розвитку дітей та підлітків. Таке підвищення інтересу призвело до збільшення кількості шкіл та танцювальних студій. Кожна 3 них обирає свою індивідуальну методику навчання i створюе відповідний навчально-виховний клімат спілкування у середені колективу. Однак завершальним етапов великої творчої роботи є сценічний виступ і як наслідок - збільшення кількості регіональних та національних феестивалів танцю, які дають змогу для одночасної демонстрації творчого доробку танцювальних шкіл, студій, колективів.

Одночасно з процесами актуалізації творчих методик та навчальних систем в Україні збільшилась кількість навчальних закладів, що надають можливість отримати професійну освіту хореографра, педагога або виконавця в танщювальному колективі (мистецькій компанії). Підвищена потреба у заняттях дітей та підлітків танцем логічно спонукає до відкриття нових структур і реалізації творчих проектів у сфрері хореографiї. Цей процес, в свою чергу, мав би призвести до розширення діапазону спілкування професійної спільноти, де можна було б проаналізувати ефрективне чи якісне збільшення кількості незалежних танцювальних компаній, танцювальних вистав на незалежних майданчиках, у муніципальних та національних театрах.

На жаль, аналіз існуючих інформаційних ресурсів, що пишуть про сучасний театр в Україні доводить, що танець все ще майже неможливо побачити в репертуарах театрів, а поява незалежних компаній $є$ настільки епізодичною, що залишається непоміченою для експертів, журналістів та глядача. В цей же час Свропейський досвід показує, що саме фрестивалі є потужним інструментом промоушену нових спектаклів та сприяють розвитку того чи іншого напрямку в сценічному мистецтві. Розуміння зв'язків між розвитком фоестивального руху та розвитком профресійної спільноти сучасного танцю допоможе розробити стратегії та форми існування сучасних фестивалів в Україні.

Аналіз останніх досліджень і публікацій. Фестивалям та фестивальному руху в Україні присвячено дослідження вітчизняних науковців: М.М. Близнюка, С.А. Вітамінової, О.А. Доманської, С.П. Зуева, О. Литовки, А.В. Семенюка, Г.І. Хрома, Д.І. Манелюка.

Фестиваль 3 точки зору його спроможності створювати культурні комунікації досліджено в роботах Л. Галеєвої, С. Соболевської, С. Шумакової та ін. Фестивальному руху як важливої складової культурного життя України XX-XXI ст. присвячені статті С. Виткалова (2016), С. Зуева (2007), О. Литовки (2013), А. Пискач (2011) та ін.

Велику дослідницьку та аналітичну роботу проводять автори електронного ресурсу http://ietm.org. Цей ресурс презентуе роботу організащії, назва якої розшифровуеться як «Informal European Theatre Meetings» (Недормальні Зустрічі Свропейських Театрів). Розділ «Публікації» містить велику кількість звітів та матеріалів досліджень щодо перформативного мистецтва та мистецьких фестивалів в Свропі. Наприклад, в статті Daphne Tepper "Can the show go on"
(2017) авторка розглядає місце та роль фрестивалів в культурній «екосистемі»: чи вони дійсно спроможні залучати нову аудиторію чи тільки використовують фінансові ресурси та займають креативні простори, обмежуючи можливості інших культурних ініціатив [2, с. 2].

Виділення невирішених раніше частин загальної проблеми. В статті «Танцювальні фестивалі України як складова фрестивального туризму» (2019) дослідники Наталія Горожанкіна, Зоя Бойко, Костянтин Горб зробили спробу класифікувати та проаналізувати фестивалі танцю в Україні [6, с. 129-137]. Зроблені висновки базуються тільки на привабливості фестивалів танцю як складової фрестивального туризму. Авторами частково досліджено аматорські фестивалі, але не згадано жоден з професійних. На жаль інших матеріалів, які були б повністю присвячені дослідженню таких подій знайти неможливо. Ірунтовного аналізу цього творчого виду публічного представлення результатів мистецької та творчої діяльності чи масового святкового дійства, що включає огляд чи демонстрацію досягнень в українській хореографічній мистецькій культурі немає. Це спонукає стверджувати, що тему зв'язку між розвитком фестивального руху і професійної спільноти в Україні грунтовно і науково не досліджено.

Постановка завдання. Мета статті - проаналізувати загальні тенденції в організації існуючих в Україні фестивалів танцю та класифрікувати їх за програмою творчих виступів (кодифікувати), охопленням категорій глядачів та учасників, технічними можливостями, комунікацією із 3MI та інше. Також залишається важливим завдання окреслити проблемні питання навколо спроможності фестивалів сприяти профресіоналізації танцювальної спільноти для подальших досліджень.

Як свідчить світовий та вітчизняний досвід, фестивалі визначають напрями розвитку мистецтва, продукують нові ідеї, відкривають нові можливості творчої діяльності. Фестиваль (назва яких, похідна від фрранцузької «festival» свято; від лат. festivus - веселий, святковий), фріксує соціальне спрямування даного дійства, водночас $\epsilon$ практичною перевіркою новацій, визначення пріоритетів і пошуком неторованих шляхів розвитку культури та мистецтва [5, с. 111-115].

Предметом аналізу цієї статті є дослідження різновидів мистецьких фестивалів в царині сучасного танцю та визначення їх спроможності реалізовувати поставлені цілі та завдання в контексті профресіоналізації танцювальної спільноти.

Виклад основного матеріалу дослідження. Досліджуючи проблемність даної теми, маючи досвід організатора єдиного в Україні щорічного міжнародного фрестивалю танцювальних театрів Zelyonka FEST з 2010 року, усвідомлюю складність та комплексність завдань, які ставлять перед собою організатори масштабних мистецьких проектів. Фестиваль був створений 3 метою розвитку професійного мистецтва та профресійних танцювальних компаній, створення майданчику для комунікації всередині танцювальної спільноти та з глядаць- 
кою аудиторією. Програмні цілі організації цього фрестивалю можна фрактично об'єднати в дві великі групи, до кожної 3 яких входять різні форми активності з боку організаторів. Перша група завдань - це сприяння розвитку танцювальної спільноти, друга група - сприяння розвитку глядацької аудиторії.

Не можна заперечувати, що існують фестивальні проекти, які націлені суто на розвиток профресійної спільноти. Такі події здебільшого називаються «форум» і вони не передбачають наявності глядачів. Назва «форум» походить від латинського «forum» - площа, двір [7, с. 354], тобто це просто відкритий простір для заходів в містах Стародавнього Риму. У сучасному словнику «форум» це широкі представницькі збори [8, с. 173], які також включають в себе поняття "з'їд», «конфреренція» [1, с. 700]. Проте ці заходи передбачають підготовку звітів (резолюцій, висновків, матеріалів конференцій) щодо дискусій та обговорень, 3 якими можуть ознайомитися всі бажаючі, хто не мав можливості взяти участь у форумі. 3 іншого боку існують події, що не передбачають «сприяння розвитку профресійної спільноти». В цю категорію зазвичай попадають сольні виступи колективів або збірні концерти, головна мета яких - показ створених вистав глядачам і комунікація з ними (обговорення або анкетування).

Багато дослідників мистецьких фестивалів, зокрема О.Литовка в статті «Фестивальний рух України в період незалежності», акцентують увагу на економічній цінності фестивалю як об'єкту «подієвого туризму» (event tourism): «Розвиток в їзного туризму стимулює економічний розвиток міста, регіону, країни. Можна стверджувати, що фоестиваль $є$ каталізатором туристичного ринку.» [5, с. 111-115] Зрозуміло, що економічна ефективність фестивалю дає можливість не тільки презентувати цікаві спектаклі та перформанси для ширшої аудиторії, сприяючи поширенню інформації про нових виконавців, але і виплачувати гідні гонорари за їх виступи. В сьогоднішній час питання виплати авторських гонорарів учасникам фестивалів набуває все більшої актуальності, так як такої практики на українських фестивалях майже не існує.

Організація фестивалів дозволяе також залученню інвестиційних чи спонсорських коштів, які частково можуть бути скеровані на розвиток інфраструктури місця проведення заходу. Разом 3 тим, велика кількість глядачів та запропоновані їм додаткові послуги обслуговуваннясервісу (харчування, пригощення, сувенірна продукція, екскурсійні програми тощо) дозволяють акомулювати інші додаткові ресурси для успішної реалізації проекту.

32008 року в Україні різко підвищився інтерес до занять різними формами сучасного танцю серед непрофресійної аудиторії. Головним чинником цього мистецького явища стала поява на українському телебаченні декількох розважальних телевізійних шоу, в яких учасники змагались у виконанні танцювальних етюдів, в тому числі під час прямих едрірів. Такий сплеск цікавості до танцю призвів до заснування великої кількості танцювальних шкіл, студій та гуртків. Це в свою чергу спричинило збільшення кількості фрестивалів танцю або мистець- ких фрестивалів, в яких танець став однією з частин фестивальної програми.

Такий підвищений інтерес 3 боку аматорських творчих колективів i ïx керівників мав би стати згодом поштовхом і для розвитку профресійної хореографрічної спільноти. Діти протягом певного часу навчаються у гуртках і танцювальних студіях, найбільш обдаровані можуть вступати у фрахові Виші, для того щоб отримати знання, що необхідні для отримання профресії хореографра або танцівника-виконавця. Таким чином відбувається збільшення кількості підготовлених продесіоналів, що в свою чергу мало б приводити до зростання кількості танцювальних компаній та театрів танцю. Однак у цьому питанні важливим залишається якісна фрахова підготовка спеціалістів, спеціальний відбір і проходження ними відповідних освітніх рівнів та практик.

З іншого боку цей кількісний показник фрахівців танцю не обов'язково має збільшуватись за рахунок професійних навчальних закладів, бо існуе багато прикладів профресійних виконавців дуже високого рівня, які не мають профресійної освіти. Вони мають хорошу технічну підготовку, в силу природних даних або через заняття в хорошому аматорському колективі, з хорошим вчителем та інколи не ставлять собі за мету здобуття освіти, а інколи - швидко заробити гроші, оскільки вік доброго танцівника обмежений. Це задовільняе хореографрів-постановників не тільки з України але навіть із Європи та США, оскільки в мистецькій діяльності наявність таланту та високих професійних якостей $є$ головним критерієм профресійної успішності.

Насправді ж збільшення кількості компаній (починаючи з 2008 року) є настільки невеликим, що глядацька аудиторія ціеї тенденції навіть не помічае, а рівень комунікацій в профресійній спільноті є настільки низьким, що не сприяе поширенню досвіду та розширенню контактів серед митців в середині країни. 3 іншого боку зрозуміло, що збільшення кількості компаній та вистав сучасного танцю є не единим показником за яким можна аналізувати розвиток спільноти. Сюди можна додати збільшення кількості танцювальних шкіл та студій, що відповідають певним стандартам мистецької освіти; збільшення кількості розважальних шоу, профресійних шоу-балетів, що працюють в Україні або гастролюють за кордоном. Предметом дослідження цієї статті є дослідження зв'язку між якістю фрестивалів та рівнем розвитку профресійної спільноти, а також фракторів які сприяють такому розвитку.

Більшість вимог документу «Положення про організацію фестивалю», які існують в Україні, копіюють одне одного як під копірку. На цей фракт можна було б не звертати уваги, якби існувала звітність, за якою можна проаналізувати успішність тих чи інших проектів. Все, що можна знайти за результатом проведення події - це фотозвіти в соціальних мережах, які створюють яскраву картинку але не дають ніякої інформації щодо ефективності чи профессійності організаторів та події в цілому.

Для того, щоб дати відповідь на питання, що виникають під час аналізу за результатами ор- 
ганізації мистецьких фрестивалів, слід окреслити критерії оцінки їх ефрективності проведення.

В контексті цієї статті звертаємо увагу перш за все на едрективність існуючих фрестивалів з точки зору їх впливу на розвиток професійних танцювальних компаній та виконавців.

По-перше, хочу сорормулювати критерії, за якими можна провести аналіз фестивалів сучасного танцю та сучасної хореографіï. Відповідно цих критеріїв умовно можна поділити фестивалі на дві категорії: профресійні та аматорські. Це не виключає наявність таких, що поєднують в своїй концептуальній та організаційній структурі ознаки профресійних і аматорських одночасно.

Критерії аналізу (оцінки) мистецьких фестивалів танцю:

- наявність відбору учасників за тими чи іншими критеріями;

- можливість представити роботу з виконанням технічних вимог виконавців (технічного райдеру);

- наявність освітньої та нетворкінгової складової в рамках фрестивалю;

- комунікація фестивалю з місцевими та національними 3MI, стейкхолдерами (PR та маркетинг);

- наявність журі або/та експертної ради фестивалю.

Згідно першого пункту можна розділити всі фрестивалі на такі, що мають попередній відбір учасників та такі, що його не мають. До першої категорії потрапляють мистецькі фрестивалі, що мають прозору систему відбору учасників за певними критеріями. Зазвичай для участі в подібних фрестивалях танцю треба надіслати якісне відео роботи, яка пропонуеться. При цьому склад експертної ради, що оцінюе і дає допускає роботи до участі має бути озвучений до початку відбору. Такий підхід формує довіру учасників та розуміння вимог до заявки.

3 іншого боку знаходяться фрестивалі, що пропонують участь для всіх бажаючих, незалежно від рівня підготовки та художньої цінності робіт. Для більшості таких фестивалів единим критерієм для участі є можливість сплатити реєстраційний внесок.

Зрозуміло, що відсутність будь-якого відбору не сприяе розвитку критичного відношення до власної творчості та роботи своїх колективи i часто сприяе потраплянню абсолютно різних за рівнем колективів в програму фестивалю. Як результат такого підходу, що зумовлений суто бажанням організаторів збільшити касу фестивалю, більш сильні учасники відмовляються від подальшої участі в подібних проектах. Колективи, що залишаються, продовжують «змагатися» 3 виконавцями такого ж низького рівня як вони самі, при цьому отримуючи дипломи, кубки та нагороди. Це приводить до поступової деградащії колективів та фрестивалю, зниження загального рівня учасників і поступового закриття проекту. I, звичайно, має негативний вплив на профресійний виконавський рівень танщівників та хореографрів.

Згідно другого пункту критеріїв до аналізу профресійних фестивалів можна віднести такі, що дають можливість показу своєї роботи 3 виконанням всіх технічних вимог виконавця. До таких вимог відносяться:
- наявність майданчику необхідного розміру;

- наявність покриття підлоги необхідної якості;

- можливість розміщення необхідних декорацій;

- наявність необхідного освітлення;

- наявність якісної звукопідсилюючої апаратури;

- можливість проведення технічної репетиції та налагодження необхідних параметрів світла та звуку.

Фестивалі іншої категорії не створюють для учасників необхідних умов для виконання робіт. Таким чином учасник не має можливості втілити задум постановників вистави або номеру і як наслідок оцінювання таких вистав або номерів відбувається неадекватно їх художньої якості. Будьякий профресійно зроблений твір, що створюється для сцени, складається з багатьох складових: piвень майстерності виконавців, унікальність хореографічного матеріалу, сценографія, світлограopiя, костюм. За відсутності будь-якої технічної складової стає фрактично неможливим об’єктивно ощінити творчий задум авторів спектаклю.

Фактично на аматорських фрестивалях всі виконавці поставлені в абсолютно однакові умови за всіма технічними можливостями. 3 одного боку це створюе ілюзію «справедливості» та «рівності умов" для всіх учасників. Разом 3 тим, з іншого боку це нівелюе сутність сценічного мистецтва, в якому будь-який продукт є результатом роботи декількох митців і кожна його складова $є$ унікальною. Якщо фестиваль запрошує учасника 3 виставою до участі, то він має забезпечити можливості показу згідно вимог учасника. Рівність умов для всіх має бути створена за рахунок надання можливості представити свою роботу за наявності необхідних технічних засобів, при якій не обезцінюеться значення різних методів виразності в перформативному мистецтві.

Освітня та нетворкінгова складові є базовими для любого фестивального проекту. Багато хто 3 дослідників каже, що фестиваль $є$ майданчиком для обміну досвідом, створення нових професійних зв'язків, утворення творчих партнерств та інше. Свропейське дослідження фрестивального руху робить висновок, що «Networking is essential for festival culture and this operates at different levels. Our research has identified three types of networks: artistic / professional networks; economic networks comprising funding agencies and sponsors; and commercial networks in the form of the promoting industry in specific arts fields (film industry, publishing industry, music industry etc.) or in terms of collaborating partners (such as other festivals)» [4].

В цій статті звернуто увагу саме на можливості профресійного нетворкінгу між учасниками. Для цього до основної програми фестивалю, яка зазвичай складається з сценічних виступів та виступів в публічних просторах, додаються воркшопи, майстер-класи, лекції, відкриті обговорення та панельні дискусії. Окрім цього організатори мають свідомо створювати та організовувати фрізичний простір для комунікації учасників, залучаючи їх до обговорення питань розвитку спільноти, діяльності танцівників та хореографрів в аматорських колективах і профресійних компаніях. 
Міжнародні фестивалі це не тільки показ найкращого, а насамперед спорідненість та спільність творчих пошуків митців. Міжнародне театрально-фестивальне життя - це «зустріч однодумців, спілкування митців, еднання праці цехів і, найголовніше, обмін досвідом», зазначає О.А. Доманська у статті «Фестиваль як самостійний та самодостатній суб'єкт театрального процесу» [3, с. 18-21].

Четвертий критерій аналізу фестивалів передбачає проведення активної рекламної та PRкампанії для залучення у перегляді фестивалю глядачами. Без цих інформаційно-комунікаційних заходів існування фестивалю втрачае сенс і перетворюеться в суто професійну подію для обміну досвідом між колективами та хореографрами. Свропейські дослідники роблять акцент на залученні «нових медіа» для промоушену фестивальних подій та трансляції цінностей фестивалю: «All artistic genres are being affected by 'new media' in terms of reproduction and dissemination. These developments are bringing about a further opening up and democratization of the arts in addition to breaking down the traditional barriers of access and value signification. In this new polyphonic environment, festivals are transformed into 'publicity' channels for new artists as well as into 'filters' for assigning value» [4].

Цей пункт є одним з ключових пунктів, які врешті-решт забезпечують формування глядацької аудиторії навколо фрестивальних подій i безпосередньо сприяють розвитку сценічного та перформативного мистецтва. Саме наявність постійної глядацької аудиторії, що зацікавлена у відвідуванні заходів і слідкуе за подіями в царині мистецтва сучасного танцю, створюе мотивацію для розвитку професійної спільноти у світі танцю.

На жаль, навіть великі фестивалі хореографічного мистецтва на кшталт Feel the Beat (організатор Олександр Скиба) або Помаранчевий Пелікан (організатор Ольга Обласова) взагалі не приділяють уваги промоції фестивалю для широкої глядацької аудиторії. Ці фестивалі (як i багато інших) мають досить високий рівень учасників але в глядацькій залі присутні саме учасники фестивалю, ї тренери, хореографи та батьки. Таким чином взагалі не відбуваеться розширення глядацької аудиторії і створюеться враження, що сучасна хореографія цікава тільки тим, хто сам нею займаеться.

Наявність журі не $е$ обов'язковою складовою профресійних фрестивалів, проте є обов'язковою майже для всіх аматорських. Більшість фестивалів першої категорії не мають мети виявляти «кращих» та змагального контексту в цілому. Їх мета - презентувати якнайширший склад учасників високого рівня, забезпечувати можливості для нетворкінгу, а також певну кількість аудиторії та експертів (в тому числі критиків та журналістів).

Для фестивалів другої категорії головним є змагання, в результаті якого найкращих нагороджують, а найгірші отримують заохочувальні дипломи. Але і в першому і в другому випадку, якщо експертне журі існуе (навіть на стадії відбору до участі), його склад мае бути оголошеним до запрошення учасників до участі. Таким чином забезпечуеться прозорість та довіра до експертної складової фестивалю, а також розуміння критеріїв, які використовуе журі на етапі відбору та оцінки. Окрім того, іменитість (з почесними званнями) складу журі може впливати і на статус фестивалю, оскільки кожен керівник прагне щоб його творчу роботу було оцінено фахівцями високого рівня.

На мій погляд $є$ абсолютно нормальним те, що різні митці, що працюють в жанрі сучасного танцю (contemporary dance) або сучасної хореографії в цілому можуть мати різні погляди на те, яким має бути сучасний танець. Виходячи 3 цього можна зрозуміти і те, що члени журі (або експертної ради) можуть мати різну оцінку тіеї чи іншої роботи. Залишаеться для роздумів питання: «Чи $є$ правильним в рамках мистецького фестивалю виводити «середній бал», усереднюючи оцінку всіх суддів?».

Цікавим $е$ кейс організації роботи журі в рамках конкурсної програми для молодих хореографів сучасного танцю фестивалю Zelyonka FEST. В роботі журі брало участь четверо експертів з Польщі, Великобританції, Латвії та Росії. Кожен з них обирав три найкращих роботи з 28 , що були показані в рамках конкурсу і оголошував свій власний список переможців, фрахово аргументуючи свій вибір роботи. Виявилось, що найкращою роботою всі експерти назвали один і той самий - перформанс "Свідомість (Під)» дуету у складі випускників кафедри сучасної хореографії КНУКІМ Владислава Детюченко та Богдана Кириленко.

Цей факт став свідченням, що хороша професійна робота завжди буде об'єктивно і одностайно-високо оцінена незалежним журі, позбавленим від сторонніх впливів на їх думку.

Висновки 3 даного дослідження. Дослідження та аналіз існуючих фестивалів сучасного танцю та сучасної хореографії в Україні показуе, що вони, на жаль, задовольняють суто інтереси аматорських шкіл та танцювальних колективів. Цей інтерес полягае в площині обкатки танцювальних номерів на "великій сцені» та мотивації танцівників для подальших занять. 3 ціею метою керівники колективів та хореографи зазвичай обирають більш масштабні фестивалі, з більшою кількістю учасників та більшою сценою. Не менш важливим є фактор вартості вступного внеску участі в тому чи іншому фестивалі, який інколи стає недосяжним бар'ером для колективів-початківців.

Аналізуючи окремий досвід проведення фестивалів можна також зробити висновок, що такі фестивалі не сприяють професіоналізації танцівників аматорських колективів. По-перше, на таких фестивалях не створюеться професійне коло спілкування для аматорів. Саме таке розширення формату фестивалів могло б сприяти та допомагати аматорам обрати свое майбутне в роботі хореографа. По-друге, не створюеться коло глядацької спільноти, яка була б зацікавлена в перегляді танцювальних вистав та перформансів, відвідувала б подібні події в своему місті. Через це дуже значущою залишається проблема відвідуваності вистав сучасного танцю як в малих містах, так і в містах-мільйонниках. 


\section{Список літератури:}

1. Великий енциклопедичний ілюстрований словник. В. В. Богатиренко, Т. І. Зав’язкіна, Ю. С. Меженко. Донецьк : ТОВ «ВКФ «БАО», 2012. 768 с.

2. Daphne Tepper. Can the show go on. URL: https://www.ietm.org/en/publications/can-the-show-go-on

3. Доманська О. А. Фестиваль як самостійний та самодостатній суб’ект театрального процесу / Духовна культура як домінанта українського життетворення : зб. матер. Всеукр. наук.-практ. конф., м. Київ, 22-23 груд. 2005 р. Київ : ДАКККіМ, 2005. Ч. II. 64 с.

4. Final Report Summary - EURO-FESTIVAL (Art Festivals and the European Public Culture) / CORDIS EU research results. URL: https://cordis.europa.eu/project/id/215747/reporting/en

5. Литовка О. Фестивальний рух України періоду її незалежності / О. Литовка. Вісник КНУКіМ. Серія : Соціальні колунікацї. 2013. Вип. 2.112 с.

6. Наталія Горожанкіна, Зоя Бойко, Костянтин ГОРБ. Танцювальні фестивалі України як складова фестивального туризму. Наукові записки Тернопільського національного педагогічного університету ілені Володимира Гнатюка. Сер. Географбія. Тернопіль : ТНПУ ім. В. Гнатюка, 2019. № 1. Вип. 46. С. $129-137$.

7. Oksfordskaya illyustrirovannaya entsiklopediya v 9-ti tt. Per s angl. 2-t izd. Ispr. Moskva : Izdatelskiy Dom «INFRA-M», Izdatelstvo «Ves Mir», 2000. T. 3 : Vsemirnaya Istoriya. S drevneishih vremen I do 1800 goda. 408 p.

8. Sovremennaya ukrainskaya entsiklopediya. Kharkov : Klub Semeynogo Dosuga, 2007. T. 15. 416 p.

\section{References:}

1. V. V. Bohatyrenko, T. I. Zaviazkina, Yu. S. Mezhenko. (2012) Velykyi entsyklopedychnyi iliustrovanyi slovnyk. [Large encyclopedic illustrated dictionary]. Donetsk : TOV «VKF «BAO». (in Ukrainian)

2. Daphne Tepper. Can the show go on. Proceeding of the. URL: https://www.ietm.org/en/publications/can-the-showgo-on

3. Domanska O. A. (2005) Festyval yak samostiinyi ta samodostatnii subiekt teatralnoho protsesu. [The festival as an independent and self-sufficient subject of the theatrical process]. Proceeding of the Dukhovna kultura yak dominanta ukrainskoho zhyttietvorennia. (Ukraine, Kyiv, December, 22-23, 2005). Kyiv: DAKKIM, p. 64.

4. Final Report Summary - EURO-FESTIVAL (Art Festivals and the European Public Culture) / CORDIS EU research results. URL: https://cordis.europa.eu/project/id/215747/reporting/en

5. Lytovka O. (2013) Festyvalnyi rukh Ukrainy periodu yii nezalezhnosti. [Festival movement of Ukraine during its independence]. Proceeding of the Visnyk KNUKiM. Seriia: Sotsialni komunikatsii. Kyiv, p. 112.

6. Nataliia Horozhankina, Zoia Boiko, Kostiantyn HORB (2019) Tantsiuvalni festyvali Ukrainy yak skladova festyvalnoho turyzmu [Dance festivals of Ukraine as a composition of festival tourism]. Naukovi zapysky Ternopilskoho natsionalnoho pedahohichnoho universytetu imeni Volodymyra Hnatiuka. Ternopil: TNPU im. V. Hnatiuka, no. 1, vol. 46, pp. 129-137.

7. Oksfordskaya illyustrirovannaya entsiklopediya v 9-ti tt. (2000) Per s angl. 2-t izd. Ispr. Moskva: Izdatelskiy Dom «INFRA-M», Izdatelstvo "Ves Mir», T. 3: Vsemirnaya Istoriya. S drevneishih vremen I do 1800 goda. P. 408.

8. Sovremennaya ukrainskaya entsiklopediya (2007). Kharkov: Klub Semeynogo Dosuga, t. 15, p. 416. 